\title{
Staphylococcus saprophyticus subsp. bovis subsp. nov., Isolated from Bovine Nostrils
}

\author{
V. HAJEK,${ }^{1 *}$ H. MEUGNIER,${ }^{2}$ M. BES,${ }^{2}$ Y. BRUN,${ }^{2}$ F. FIEDLER,${ }^{3}$ Z. CHMELA,${ }^{4}$ Y. LASNE, \\ J. FLEURETTE, ${ }^{2}$ AND J. FRENEY ${ }^{2}$ \\ Department of Microbiology ${ }^{1}$ and Department of Pathological Physiology, ${ }^{4}$ Medical Faculty, Palacký University, \\ Olomouc, Czech Republic; Unité Propre de Recherche d'Enseignement Supérieur 1655, Medical Faculty of \\ Alexis Carrel, ${ }^{2}$ and Laboratory of Radioisotopes, Edouard Herriot Hospital, ${ }^{5}$ Lyon, France; and \\ Institute of Genetics and Microbiology, University of Munich, Germany ${ }^{3}$
}

\begin{abstract}
A new coagulase-negative subspecies, Staphylococcus saprophyticus subsp. bovis, is described on the basis of a study of five strains isolated from the anterior nares of cows. This subspecies is differentiated from the other novobiocin-resistant staphylococci by its phenotypic properties, cell wall composition, and levels of genetic relatedness. The type strain of the new subspecies is KV $12(=$ CCM 4410).
\end{abstract}

A total of 28 species and 8 subspecies are already recognized in the genus Staphylococcus, as listed in the 9th ed. of Bergey's Manual of Determinative Bacteriology (19). In addition, five new staphylococcal species have been validly published since 1992 ( $S$. muscae, $S$. pasteuri, $S$. piscifermentans, $S$. pulvereri, and $S$. vitulus) $(8,17,34-36)$.

Within the cluster of coagulase-negative staphylococci, 11 novobiocin-resistant species ( $S$. arlettae, $S$. cohnii, $S$. equorum, $S$. gallinarum, S. kloosï, S. lentus, $S$. pulvereri, S. saprophyticus, $S$. sciuri, $S$. vitulus, and $S$. xylosus $)(10,23,27,29,30,35,36)$ and two subspecies ( $S$. cohnii subsp. cohnii and $S$. cohnii subsp. urealyticus) (24) have been established so far. In this paper, a new taxonomic group of novobiocin-resistant staphylococci closely related to $S$. saprophyticus is described. These bacteria were isolated in about $7 \%$ of the nostrils of healthy cows. They were allocated on the basis of their physiological and biochemical properties, cell wall composition, and genetic relatedness to a separate subspecies, $S$. saprophyticus subsp. bovis.

\section{MATERIALS AND METHODS}

Bacterial strains. Five strains (KV $12^{\mathrm{T}}=\mathrm{CCM} 4410, \mathrm{KV} 19, \mathrm{KV} 20$, KV 30 , and KV $56=\mathrm{CCM} 4411$ ) were isolated from the anterior nares of healthy cows brought to the Olomouc slaughterhouse from North Moravia. The isolation medium was nutrient broth (Oxoid) supplemented with $7 \% \mathrm{NaCl}$ and blood agar base no. 2 (Oxoid) mixed with 5\% defibrinated ovine blood. The latter was also used for the propagation of all of the isolates.

The 20 type strains of the genus Staphylococcus (see Table 6) for the DNADNA hybridization test were obtained from the American Type Culture Collection, Rockville, Md.; the Czech Collection of Microorganisms, Masaryk University, Brno, Czech Republic; and the Deutsche Sammlung von Mikroorganismen, Braunschweig, Germany.

All of the strains were maintained as frozen suspensions in glycerol broth at $-25^{\circ} \mathrm{C}(20)$ and were also maintained in a freeze-dried state.

Phenotypic characteristics. The following properties were determined by methods previously described in detail $(11,15,17)$ : cell and colony morphology; pigmentation; motility; anaerobic growth in thioglycolate medium; production of catalase, oxidase, and coagulase in rabbit and bovine plasma; production of clumping factor, fibrinolysin, acetylmethylcarbinol, urease, arginine-dihydrolase, alkaline and acid phosphatases, cascinase, gelatinase, hyaluronidase, heat-labile and heat-stable nucleases, lysozyme, lecithinase, $\alpha$ - and $\beta$-hemolysins, $\beta$-galactosidase, indole, hydrogen sulfide, phenylalanine deaminase, ornithine and lysine decarboxylases, protein $\mathrm{A}$, and acid from carbohydrates (adonitol, arabinose, cellobiose, dulcitol, fructose, galactose, glucose, glycerol, lactose, maltose, mannitol, mannose, raffinose, rhamnose, ribose, sucrose, trehalose, turanose, and xylose) under aerobic conditions and from two other sugars (glucose and mannitol) under anaerobic conditions; nitrate reduction; hydrolysis of Tween 20, 40, and 80; hydrolysis of Na-hippurate, starch, and esculin; growth on Simmons

\footnotetext{
* Corresponding author.
}

citrate agar; and tolerance to $\mathrm{NaCl}$. In addition, the production of elastase on Elastin Congo red (ZD Letohrad, Czech Republic) agar according to the method of Janda (21) and the production of arginine arylamidase, pyrrolidonyl arylamidase, $\beta$-glucuronidase, and $N$-acetylglucosaminidase were examined with the ID 32 STAPH strip (bioMérieux, Marcy l'Etoile, France) (7).

Drug susceptibilities. The disk diffusion technique for susceptibility testing with novobiocin, bacitracin, vibriostatic compound $\mathrm{O} / 129$, and lysostaphin was used as described previously $(11,15)$. The MICs of 39 different antimicrobial agents (antibiotics, chemotherapeutics, and disinfectants) were determined by the dilution micromethod with Mueller-Hinton broth (Oxoid). The reference strains Escherichia coli CCM 3988, Staphylococcus aureus CCM 3953, S. saprophyticus CCM 883, and Micrococcus kristinae CCM 2690 served as controls.

Typing with phages. Phage typing was done according to the method of Blair and Williams (3). The tested cultures were examined with the standard sets of 23 phages (33) for human $S$. aureus strains, 12 phages (32) for bovine $S$. aureus strains, and experimental sets of 4 phages $(06,40,58$, and 93$)$ for $S$. intermedius strains (4), 2 phages (H1 and $H 4)$ for $S$. hyicus strains (16), and 7 phages $(41,63$, 138, 245, 336, 392, and 550 [National Reference Center for Staphylococci, Medical Faculty, Lyon, France]) and 15 phages $(15,27,37,155$, A6C, 71, 275, 48, 82, 456, 157A, 471A, 459, 275A, and B1 [Public Health Laboratory Service, Colindale, London, United Kingdom]) for $S$. epidermidis strains. The strains were tested at $100 \times$ the routine test dilution.

Fatty acid composition. Fatty acid profiles of lyophilized cultures were determined by gas chromatography of fatty acid methyl esters on a Chrom 41 apparatus (Laboratorní přístroje, Praha, Czech Republic) adapted for capillary gas chromatography. A column coated with free fatty acid acid phase and a flame ionization detector were used. Fatty acid methyl esters were prepared by direct transesterification with sodium methoxide (37). The reference strain $S$. saprophyticus CCM 883 was used as a standard for the analysis.

Cell wall analysis. Cells were disintegrated by shaking with glass beads, and cell walls were purified with $4 \%$ sodium dodecyl sulfate (SDS) by the procedure of Glauner et al. (13).

For total amino acid analysis, SDS-purified cell walls (CW-SDS) were hydrolyzed with $4 \mathrm{~N} \mathrm{HCl}$ for $16 \mathrm{~h}$ at $100^{\circ} \mathrm{C}$. The levels of amino acids were determined with an amino acid analyzer (LC 6001; Biotronik, Maintal, Germany). The peptidoglycan structure was deduced from the molar ratios of glutamic acid to glycine, alanine, serine, lysine, glucosamine, and muramic acid, respectively (28).

Phosphorus in cell walls was determined according to the method of Ames (1). The composition of teichoic acids was analyzed in hydrofluoric acid hydrolysates (60\% hydrofluoric acid) of cell walls (2) or by extraction and ion-exchange purification chromatography on DEAE-Sephacel in the case of the KV 19 and KV 30 strains according to the method of Kaya et al. (22). The analysis was performed by gas-liquid chromatography of peracetylated polyols and alditols. The details of the procedure have been described elsewhere (35).

DNA-DNA hybridization. Published methods for the extraction $(18,25)$ and purification (6) of DNA were used. Native DNA was labeled in vitro by nick translation with tritium-labeled nucleotides (Amersham International, Amersham, United Kingdom). The S1 nuclease method (9) was used according to the trichloracetic procedure described in detail elsewhere (14); the reassociation temperature was $60^{\circ} \mathrm{C}$. The hybridization experiments were carried out with labeled DNA from the KV 12 strain as a probe. The temperature $\left(T_{m}\right)$ at which $50 \%$ of the reassociated DNA became hydrolyzable by the $\mathrm{S} 1$ nuclease was determined (9). The difference $\left(\Delta T_{m}\right)$ between the $T_{m}$ of the homologous and heterologous reactions is an estimate of the divergence between the two DNAs (5); this procedure was done twice.

DNA base composition. The $\mathrm{G}+\mathrm{C}$ mole percent content of DNA was 
obtained after hydrolysis with nuclease P1 (Sigma, Chemical Co., St. Louis, Mo.) (12) and after reverse-phase chromatography on a Merck chromatograph (Merck-Clevenot, Nogent-sur-Marne, France) by the high-performance liquid chromatography method as described elsewhere (26). A Legionella gratiana strain (ATCC 49413) with $\mathrm{G}+\mathrm{C}$ content of $38.0 \% \pm 1 \%$ was included as a standard.

\section{RESULTS AND DISCUSSION}

The five strains investigated are gram-positive, spherical cocci that occur singly, in pairs, in short chains, and in irregular clusters and that are nonmotile and non-spore forming. All of the strains are able to grow in the presence of $10 \% \mathrm{NaCl}$ and, both aerobically and anaerobically, in the semisolid Brewer thioglycolate medium. They produce catalase and are resistant to bacitracin, vibriostatic agent $\mathrm{O} / 129$, and lysozyme but sensitive to lysostaphin. The average base composition in all the strains reached $31 \mathrm{~mol} \% \mathrm{G}+\mathrm{C}$. The characteristics mentioned above permit us to include the strains in the genus Staphylococcus.

All of the strains are coagulase, heat-stable nuclease, and clumping factor negative and novobiocin resistant. The DNADNA hybridization studies have shown that the five strains are genetically closely related on the species level and are related to $S$. saprophyticus on the subspecies level. They are, however, not related to any of the other staphylococcal species.

Description of $S$. saprophyticus subsp. bovis subsp. nov. The description of $S$. saprophyticus subsp. bovis (bo'vis. L. n. bos, a cow; L. gen. n. bovis, of a cow) is based on a total of five strains.

Physiological and biochemical characteristics. The organism has gram-positive spherical cells, 0.7 to $1.4 \mu \mathrm{m}$ in diameter, that occur singly, in pairs, in short chains, and in irregular clumps. The organism is nonmotile and non-spore forming. Colonies are circular, entire, butyrous, slightly convex with gently raised centers and glistening surfaces, and grow to $4 \mathrm{~mm}$ in diameter after 3 days of cultivation. Creamy to pale orange pigment is produced by four strains, and one strain is unpigmented. Broth cultures form with uniform turbidity and delicate deposit. Growth is very weak at $10^{\circ} \mathrm{C}$, and there is no growth at $45^{\circ} \mathrm{C}$. Colonies formed on nutrient agar supplemented with $\mathrm{NaCl}$ at a concentration up to $10.0 \%$ and only weakly at a concentration up to $12.5 \%$.

The strains are facultative anaerobes. The benzidine test for porphyrin is positive, and sodium hippurate is hydrolyzed. Nitrate is reduced. The organism is catalase and urease positive. Acid is produced from fructose, glucose, glycerol, maltose, mannitol, ribose, trehalose, and $N$-acetylglycosamine under aerobic conditions and from glucose under anaerobic conditions.

The variable characteristics of $S$. saprophyticus subsp. bovis are listed in Table 1.

None of the strains studied produce coagulase, clumping factor, fibrinolysin, elastase, arginine arylamidase, arginine dihydrolase, ornithine and lysine decarboxylases, oxidase, acid phosphatase, heat-labile and heat-stable nucleases, hyaluronidase, hemolysins, and acid from adonitol, cellobiose, dulcitol, galactose, raffinose, rhamnose, and xylose. Esculin and starch are not hydrolyzed. All strains are negative for production of hydrogen sulfide, phenylalanine deaminase, and acid from mannitol under anaerobic conditions. No growth is recorded on Simmons citrate agar and on nutrient agar in the presence of $15 \% \mathrm{NaCl}$.

Drug susceptibilities. In disk diffusion tests, resistance to novobiocin, bacitracin, and vibriostatic compound $\mathrm{O} / 129$ is noted. On the contrary, all of the strains are sensitive to lysostaphin.
TABLE 1. Variable characteristics of S. saprophyticus subsp. bovis strains

\begin{tabular}{|c|c|c|c|}
\hline Characteristic & $\begin{array}{c}\text { No. of } \\
\text { strains positive } \\
\text { (weakly positive) }\end{array}$ & $\begin{array}{l}\text { KV strains with } \\
\text { positive (weakly } \\
\text { positive) reaction }\end{array}$ & $\begin{array}{l}\text { Reaction } \\
\text { for strain } \\
\mathrm{KV} 12^{\mathrm{T} a}\end{array}$ \\
\hline Colony pigment & 4 & $12,20,30,56$ & + \\
\hline Gelatinase & $2(2)$ & $12,30,(20), 56$ & + \\
\hline Caseinase & $1(1)$ & $30,(19)$ & - \\
\hline Lysozyme & $2(2)$ & $12,20,(30),(56)$ & + \\
\hline$\beta$-Galactosidase & 3 & $12,19,30$ & + \\
\hline$\beta$-Glucuronidase & 1 & 19 & - \\
\hline Lecithinase & 1 & 19 & - \\
\hline $\begin{array}{l}\text { Hydrolysis of Tween } \\
20,40 \text {, and } 80\end{array}$ & 1 & 19 & - \\
\hline Alkaline phosphatase & 1 & 19 & - \\
\hline Acetylmethylcarbinol & 1 & 30 & - \\
\hline \multicolumn{4}{|l|}{ Acid from: } \\
\hline Arabinose & 1 & 19 & - \\
\hline Galactose & 4 & $19,20,30,56$ & - \\
\hline Lactose & 1 & 19 & - \\
\hline Mannose & 1 & 19 & - \\
\hline Sucrose & 4 & $12,20,30,56$ & + \\
\hline Turanose & 4 & $12,20,30,56$ & + \\
\hline
\end{tabular}

${ }^{a}+$, positive; -, negative.

As determined by MICs, all of the KV strains are susceptible to penicillin G (MIC [micrograms per milliliter], 0.06 to 0.1 ), ampicillin (MIC, 0.06 to 0.1 ), oxacillin (MIC, 0.2 to 0.5 ), azlocillin (MIC, 1.0 to 16.0), cephalothin (MIC, 0.2 to 0.5 ), streptomycin (MIC, 0.5 to 2.0), gentamicin (MIC, 0.06 to 0.1 ), kanamycin (MIC, 0.5), tobramycin (MIC, 0.06), netilmicin (MIC, 0.03), neomycin (MIC, 0.06), minocycline (MIC, 0.06), chloramphenicol (MIC, 4.0), erythromycin (MIC, 0.06 to 0.5 ), lincomycin (MIC, 0.06 to 0.5 ), clindamycin (MIC, 0.06 to 0.1 ), pristinamycin (MIC, 0.25 to 1.0 ), rifampin (MIC, 0.1), teicoplanin (MIC, 0.5 to 2.0 ), vancomycin (MIC, 0.5 to 1.0 ), ofloxacin (MIC, 0.2 ), and co-trimoxazole (MIC, 0.5 to 1.0). From the disinfectants tested, efficacy was recorded for ethidium bromide ( $\mathrm{MIC}, \leq 10.0$ ), acriflavine ( $\mathrm{MIC}, \leq 50.0$ ), chlorbenzalconium (MIC, $\leq 2.6$ ), chlorhexidine (MIC, $\leq 0.9$ ), and hexamidine diisothionate (MIC, $\leq 10.0$ ). All strains are resistant to $1,000 \mu \mathrm{g}$ of lysozyme per $\mathrm{ml}$. Some of the strains are resistant to tetracycline, cefotaxime, ceftriaxone, ceftazidime, pefloxacin, fusidic acid, or nitrofurantoin (Table 2).

Phage typing. None of the strains was susceptible to all 63 phages used at $100 \times$ routine test dilution.

Fatty acid profile. The strains have a branched-chain anteiso- $C_{15: 0}$ fatty acid as their dominant component. The presence of long-chain saturated unbranched fatty acids $C_{18: 0}$ and $\mathrm{C}_{20: 0}$ has also been demonstrated as typical for staphylococci $(24,31)$. In addition, evidently larger amounts of fatty acids iso- $\mathrm{C}_{15: 0}$ and particularly anteiso- $\mathrm{C}_{17: 0}$ were recorded. The determination of fatty acid patterns yielded closely related results both in the KV strains and in E $39\left(=\mathrm{CCM} 883^{\mathrm{T}}\right)$, the $S$. saprophyticus type strain (Table 3).

Cell wall analysis. The findings on the composition of pep- 
TABLE 2. MICs of various antimicrobial agents for resistant S. saprophyticus subsp. bovis strains

\begin{tabular}{lccccc}
\hline \multirow{2}{*}{$\begin{array}{l}\text { Antimicrobial } \\
\text { agent }\end{array}$} & \multicolumn{5}{c}{ MIC (mg/liter) for: } \\
\cline { 2 - 6 } & $\mathrm{KV}$ & $\mathrm{KV}$ & $\mathrm{KV}$ & $\mathrm{KV}$ & $\mathrm{KV}$ \\
& $12^{\mathrm{T}}$ & 19 & 20 & 30 & 56 \\
\hline Tetracycline & 0.06 & 0.5 & 0.1 & $4.0^{a}$ & 0.1 \\
Cefotaxime & 4.0 & $8.0^{a}$ & 2.0 & 2.0 & 4.0 \\
Ceftriaxone & $16.0^{a}$ & $16.0^{a}$ & 4.0 & $8.0^{a}$ & $16.0^{a}$ \\
Ceftazidime & $8.0^{a}$ & $8.0^{a}$ & 4.0 & $8.0^{a}$ & $8.0^{a}$ \\
Pefloxacin & 2.0 & $4.0^{a}$ & 2.0 & 2.0 & 2.0 \\
Fusidic acid & $2.0^{a}$ & $4.0^{a}$ & $2.0^{a}$ & 1.0 & 0.5 \\
Nitrofurantoin & 16.0 & $64.0^{a}$ & 32.0 & 16.0 & 32.0 \\
\hline
\end{tabular}

${ }^{a}$ Resistant.

tidoglycans are given in Table 4 . In peptidoglycans of all estimated strains, a small amount of serine was present. Except for the KV 19 strain, the glycine/serine molar ratio reached approximately half the values for $S$. saprophyticus $(30,31)$.

TABLE 3. Fatty acid profiles in whole-cell lipids of $S$. saprophyticus subsp. bovis strains

\begin{tabular}{|c|c|c|c|c|c|c|c|}
\hline \multirow{2}{*}{ Fatty acid } & \multirow{2}{*}{$\begin{array}{l}\text { Chain } \\
\text { length } \\
\text { and no. } \\
\text { of bonds }\end{array}$} & \multicolumn{6}{|c|}{$\%$ of total amt of fatty acid methyl ester ${ }^{a}$} \\
\hline & & $\mathrm{KV} 12^{\mathrm{T}}$ & KV 19 & KV 20 & KV 30 & KV 56 & E $39^{b}$ \\
\hline \multirow[t]{3}{*}{ Iso+ anteiso } & $12: 0^{c}$ & $\operatorname{Tr}$ & 0.1 & $\operatorname{Tr}$ & 0.1 & $\operatorname{Tr}$ & $\mathrm{Tr}$ \\
\hline & $13: 0$ & 0.4 & 0.2 & 0.3 & 0.3 & 0.3 & 0.3 \\
\hline & 13:0 & $\operatorname{Tr}$ & $\operatorname{Tr}$ & $\operatorname{Tr}$ & $\operatorname{Tr}$ & $\operatorname{Tr}$ & $\operatorname{Tr}$ \\
\hline \multirow[t]{2}{*}{ Iso } & $14: 0$ & 1.0 & 0.9 & 0.9 & 0.7 & 0.7 & 0.8 \\
\hline & $14: 0$ & 1.8 & 0.4 & 1.8 & 1.2 & 0.8 & 1.6 \\
\hline Iso & $15: 0$ & 5.3 & 3.1 & 5.9 & 5.4 & 7.1 & 4.1 \\
\hline \multirow[t]{2}{*}{ Anteiso } & $15: 0$ & 52.0 & 54.8 & 49.7 & 52.8 & 53.0 & 51.8 \\
\hline & $15: 0$ & 0.1 & 0.2 & 0.1 & 0.1 & 0.1 & 0.1 \\
\hline \multirow[t]{2}{*}{ Iso } & $16: 0$ & 1.1 & 2.4 & 0.9 & 1.0 & 1.4 & 1.1 \\
\hline & $16: 0$ & 4.6 & 2.0 & 4.7 & 3.6 & 2.4 & 3.8 \\
\hline Iso & $17: 0$ & 2.0 & 1.6 & 2.3 & 2.2 & 3.4 & 2.2 \\
\hline \multirow[t]{2}{*}{ Anteiso } & $17: 0$ & 13.7 & 19.7 & 13.7 & 16.9 & 16.4 & 14.0 \\
\hline & $17: 0$ & 0.1 & 0.2 & 0.1 & 0.2 & 0.1 & 0.1 \\
\hline \multirow[t]{2}{*}{ Iso } & $18: 0$ & 0.2 & 0.6 & 0.2 & 0.1 & 0.3 & 0.2 \\
\hline & $18: 0$ & 6.6 & 4.0 & 7.3 & 5.0 & 3.7 & 6.4 \\
\hline Iso & 19:0 & 1.0 & 1.1 & 1.1 & 1.4 & 1.8 & 1.3 \\
\hline \multirow[t]{2}{*}{ Anteiso } & $19: 0$ & 1.4 & 2.8 & 1.9 & 2.1 & 2.1 & 2.2 \\
\hline & $19: 0$ & 0.2 & 0.2 & 0.2 & 0.3 & 0.2 & 0.1 \\
\hline \multirow[t]{2}{*}{ Iso } & $20: 0$ & 0.1 & 0.1 & 0.1 & 0.1 & 0.1 & 0.1 \\
\hline & $20: 0$ & 7.6 & 4.7 & 8.3 & 5.8 & 5.4 & 9.1 \\
\hline Iso & $21: 0$ & 0.1 & 0.1 & 0.1 & 0.1 & 0.2 & 0.1 \\
\hline Anteiso & 21:0 & 0.1 & 0.1 & 0.1 & 0.1 & 0.1 & 0.2 \\
\hline \multirow[t]{2}{*}{ Iso } & $22: 0$ & $\operatorname{Tr}$ & & & & & \\
\hline & $22: 0$ & 0.2 & 0.2 & 0.2 & 0.2 & 0.2 & 0.3 \\
\hline
\end{tabular}

${ }^{a}$ Percentage of areas of corresponding individual fatty acid methyl esters related to the total peak areas of methyl esters analyzed. Values presented are means of two independently tested samples of one lyophilizate. Tr, trace $(<0.05 \%)$

${ }^{b}$ S. saprophyticus type strain $(=$ ATCC $15305=$ CCM 883).

c Probable identification.
TABLE 4. Composition of peptidoglycans determined from acid hydrolysates of CW-SDS

\begin{tabular}{lccccccc}
\hline \multirow{2}{*}{ Strain } & \multicolumn{7}{c}{ Molar ratio (Glu = 1) } \\
\cline { 2 - 8 } & Gly & Ala & Ser & Lys & GlcN & Mur $^{a}$ & NH $_{3}$ \\
\hline KV 12 & 3.8 & 1.9 & 0.3 & 0.9 & 2.2 & 0.9 & 0.9 \\
KV 19 & 4.0 & 2.2 & 0.7 & 0.9 & 1.0 & 0.7 & 0.8 \\
KV 20 & 3.9 & 2.1 & 0.2 & 0.9 & 1.9 & 0.8 & 0.8 \\
KV 30 & 3.4 & 2.1 & 0.2 & 0.9 & 2.0 & 0.8 & 0.7 \\
KV 56 & 3.7 & 1.9 & 0.3 & 0.8 & 2.0 & 0.8 & 0.7 \\
\hline
\end{tabular}

${ }^{a}$ Mur, muramic acid.

Smaller amounts of serine coincide with the lysostaphin susceptibility observed in all strains. The peptidoglycan type of the KV strains was determined as Lys-Gly 3.4-4.0, Ser $_{0.2-0.7}$. The amount of $\mathrm{NH}_{3}$ in the hydrolysates may indicate amidation on the $\alpha$-carboxyl of glutamic acid.

The data concerning the accessory carbohydrate polymers in the cell walls are summarized in Table 5. Significant amounts of phosphorus in the prepared cell walls indicated the presence of teichoic acids. The KV $12^{\mathrm{T}}$, KV $20, \mathrm{KV} 30$, and $\mathrm{KV} 56$ strains exhibited ribitol teichoic acids with partial substitution by $N$-acetylglucosamine. In the case of the KV 56 strain, glucose may be a minor substituent of ribitol in addition to $N$ acetylglucosamine. The teichoic acid of the KV 19 strain was found to be distinctly different. Glycerol (Gro) is the polyol with typical behavior on hydrofluoric acid hydrolysis, allowing us to assume that chains consisting of [-P-GlcNAc-P-Gro-] repeating units are present. It could explain the rather large amount of phosphorus in this type of cell wall teichoic acid. Glucose may function as a substituent.

Protein A has not been detected in the strains.

DNA-DNA hybridization. The five KV strains form a genetically homogeneous group. The DNA relatedness results obtained with labeled reference DNA from the KV $12^{\mathrm{T}}$ strain are given in Table 6 . The other KV strains are related at species levels of 94 to $99 \%$, and the S. saprophyticus type strain, CCM 883 , is related at a subspecies level of $71 \%$. The type strains of other staphylococcal species show relatedness at levels of no more than $32 \%$.

DNA base composition. The $\mathrm{G}+\mathrm{C}$ contents of the DNA of all strains tested varied in a close range between 30.9 and 31.3 mol\%.

Description of the type strain. The type strain KV 12 $\left(=\mathrm{CCM} 4410^{\mathrm{T}}\right)$, isolated from the anterior nares of a cow, has the characteristics given for the species above and in Tables 1 , 2 , and 3. The peptidoglycan structure is of the Lys-Gly $_{3.8}, \mathrm{Ser}_{0.3}$ type. The $\mathrm{G}+\mathrm{C}$ content of its DNA was found to be 31.0 mol\%.

Distinguishing characteristics. $S$. saprophyticus subsp. bovis

TABLE 5. Composition of teichoic acids

\begin{tabular}{lccccc}
\hline \multirow{2}{*}{ Strain } & \multirow{2}{*}{$\begin{array}{c}\text { Amt of phosphorus } \\
\text { (nmol/mg of CW-SDS) }\end{array}$} & \multicolumn{5}{c}{ Occurrence of: } \\
\cline { 3 - 6 } & & Glycerol & Ribitol & Glucose & Glucosamine \\
\hline KV 12 & 583 & - & + & - & + \\
KV 19 & 923 & + & - & + & + \\
KV 20 & 597 & $-{ }^{b}$ & + & - & + \\
KV 30 & 500 & $-^{b}$ & + & - & + \\
KV 56 & 543 & $-{ }^{b}$ & + & $(+)$ & + \\
\hline
\end{tabular}

${ }^{a}$ Teichoic acid extracted and fractionated on DEAE-Sephacel.

${ }^{b}$ Minor amounts of glycerol are not indicative of the occurrence of a glycerol teichoic acid but probably derive from linkage units. 
TABLE 6. DNA relatedness among $S$. saprophyticus subsp. bovis and other species in the genus Staphylococcus

\begin{tabular}{|c|c|c|}
\hline Source of unlabeled DNA ${ }^{a}$ & \multicolumn{2}{|c|}{$\begin{array}{l}\% \text { reassociation at } 60^{\circ} \mathrm{C} \\
\text { with labeled DNA from } \\
\text { S. saprophyticus subsp. bovis } \\
(\mathrm{KV} 12=\mathrm{CCM} 4410)\end{array}$} \\
\hline \multirow{2}{*}{\multicolumn{3}{|c|}{ S. saprophyticus subsp. bovis }} \\
\hline & .............. 1 & $100^{b}$ \\
\hline KV 19 & ................ & 94 \\
\hline KV $20 \ldots \ldots \ldots \ldots \ldots \ldots \ldots$ & ................... & 99 \\
\hline KV 30 & ..................... & 99 \\
\hline KV 56 & ..................... & 99 \\
\hline S. saprophyticus CCM $883^{\mathrm{T}}$. & .................... & $71(1)^{c}$ \\
\hline S. caprae $\mathrm{CCM} 3573^{\mathrm{T}}, \ldots \ldots \ldots$. & .................. & 32 \\
\hline S. intermedius CCM $5739^{\mathrm{T}}$.. & ..................... & 26 \\
\hline S. warneri $\mathrm{CCM} 2730^{\mathrm{T}} \ldots \ldots \ldots$ & $\ldots$ & 24 \\
\hline S. arlettae DSM $20672^{\mathrm{T}} \ldots \ldots$ & 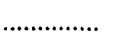 & 22 \\
\hline S, capitis CCM $2734^{\mathrm{T}} \ldots \ldots \ldots \ldots$. & 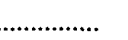 & 21 \\
\hline S. aureus CCM $885^{\mathrm{T}}$................ & $\ldots$ & 20 \\
\hline S. gallinarum CCM $3572^{\mathrm{T}}$.. & ............ & 20 \\
\hline S. haemolyticus CCM $2737^{\mathrm{T}}$ & ..................... & 20 \\
\hline S. xylosus CCM $2738^{\mathrm{T}} \ldots \ldots \ldots \ldots$ & $\ldots$ & 20 \\
\hline S. kloosii DSM $20676^{T} \ldots \ldots \ldots$ & $\ldots+\ldots \ldots \ldots . .$. & 18 \\
\hline S. delphini DSM $20771^{\mathrm{T}} \ldots \ldots$. & ...................... & 17 \\
\hline S. simulans $\mathrm{CCM} 2705^{\mathrm{T}} \ldots \ldots$ & & 17 \\
\hline S. hominis DSM $20328^{\mathrm{T}} \ldots \ldots$ & ................... & 15 \\
\hline S. cohnii CCM $2736^{\mathrm{T}} \ldots \ldots \ldots \ldots$ & ..................... & 13 \\
\hline S. auricularis ATCC $33753^{\mathrm{T}}$ & ...................... & 10 \\
\hline S. equorum DSM $20674^{\mathrm{T}} \ldots .$. & ....................... & 10 \\
\hline S. carnosus DSM $20501^{\mathrm{T}} \ldots$ & .................... & 9 \\
\hline S. caseolyticus ATCC 13548 & ................... & 6 \\
\hline S. epidermidis CCM $2124^{\mathrm{T}}$.. & ..................... & 2 \\
\hline
\end{tabular}

${ }^{a}$ ATCC, American Type Culture Collection, Rockville, Md.; CCM, Czech Collection of Microorganisms, Masaryk University, Brno, Czech Republic; DSM, Deutsche Sammlung von Mikroorganismen, Göttingen, Germany.

${ }^{b}$ Percent relatedness.

${ }^{c}$ Value in parentheses represents $\Delta T_{m}$ (in degree Celsius).

can be phenotypically distinguished from $S$. saprophyticus subsp. saprophyticus on the basis of smaller colony diameters, nitrate reduction, ability to produce pyrrolidonyl arylamidase but not acetylmethylcarbinol, and fermentation of galactose and ribose (Table 7).

The properties useful in the identification and separation of the new taxon $S$. saprophyticus subsp. bovis from the other novobiocin-resistant staphylococcal species and subspecies are listed in Table 8 . It can be recognized by the colony size, reduction of nitrates, production of urease and acid from ribose, and its inability to hydrolyze esculin and produce acid from cellobiose, raffinose, and xylose.

TABLE 7. Differentiation of subspecies of the species S. saprophyticus

\begin{tabular}{lcc}
\hline \multirow{1}{*}{ Characteristic } & \multicolumn{2}{c}{$\begin{array}{c}\text { Reaction of } S \text {. saprophyticus } \\
\text { subsp. }{ }^{a}:\end{array}$} \\
\cline { 2 - 3 } & bovis & saprophyticus \\
\hline Colony diam $>5 \mathrm{~mm}$ & - & + \\
Nitrate reduction & + & - \\
Pyrrolidonyl arylamidase & + & - \\
Acetoin & $\mathrm{v}(-)$ & + \\
D-Galactose & $\mathrm{v}(+)$ & - \\
D-Ribose & + & - \\
\hline
\end{tabular}

${ }^{a}+$, positive; $\mathrm{v}$, variable; - , negative. Symbols in parentheses are mostly positive or negative.

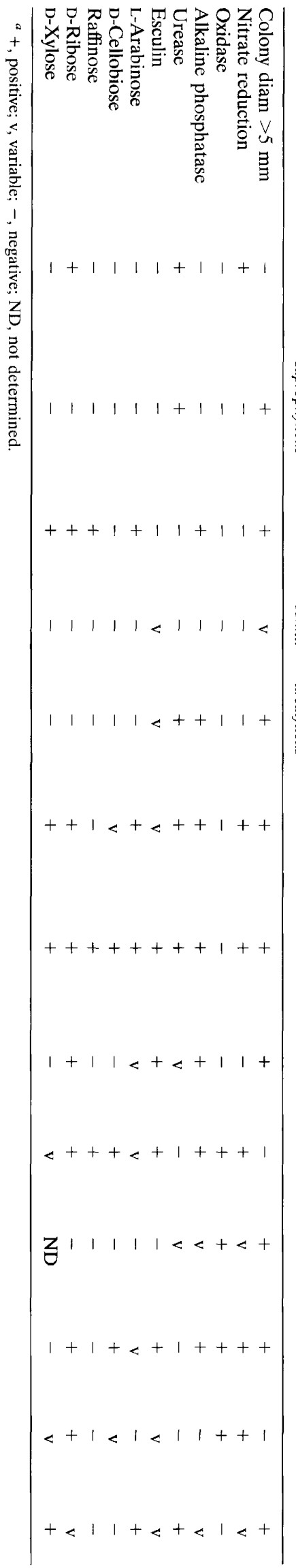

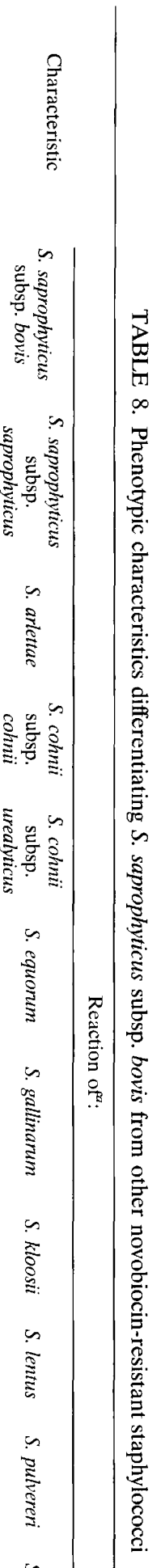




\section{REFERENCES}

1. Ames, B. N. 1966. Assay of inorganic phosphate, total phosphate and phosphatases. Methods Enzymol. 8:115-118.

2. Anderson, A. J., R. S. Green, and A. R. Archibald. 1977. Specific determination of ribitol teichoic acid in whole bacteria and isolated walls of Bacillus subtilis W23. Carbohydr. Res. 57:C7-C10.

3. Blair, J. E., and R. E. O. Williams. 1961. Phage typing of staphylococci. Bull. W. H. O. 24:771-784.

4. Blouse, L., and W. E. Meekins. 1968. Isolation and use of experimental phages for typing Staphylococcus aureus isolates from sentry dogs. Am. J. Vet. Res. 29:1817-1822.

5. Brenner, D. J. 1978. Characterization and clinical identification of Enterobacteriaceae by DNA hybridization. Prog. Clin. Pathol. 7:71-117.

6. Brenner, D. J., A. C. McWorter, J. K. Leete Knutson, and A. G. Steigerwalt. 1982. Escherichia vulneris: a new species of Enterobacteriaceae associated with human wounds. J. Clin. Microbiol. 15:1133-1140.

7. Brun, Y., M. Bes, J. M. Boeufgras, D. Monget, J. Fleurette, R. Auckenthaler, L. A. Devriese, M. Kocur, R. R. Marples, Y. Piemont, B. Poutrel, and F. Schumacher-Perdreau. 1990. International collaborative evaluation of the ATB 32 Staph gallery for identification of the Staphylococcus species. Zentralbl. Bakteriol. 273:319-326.

8. Chesneau, O., A. Morvan, F. Grimont, H. Labischinski, and N. El Solh. 1993. Staphylococcus pasteuri sp. nov., isolated from human, animal, and food specimens. Int. J. Syst. Bacteriol. 43:237-244.

9. Crosa, J. H., D. J. Brenner, and S. Falkow. 1973. Use of a single-strand specific nuclease for analysis of bacterial and plasmid deoxyribonucleic acid homo- and heteroduplexes. J. Bacteriol. 115:904-911.

10. Devriese, L. A., B. Poutrel, R. Kilpper-Bälz, and K. H. Schleifer. 1983. Staphylococcus gallinarum and Staphylococcus caprae, two new species from animals. Int. J. Syst. Bacteriol. 33:480-486.

11. Freney, J., Y. Brun, M. Bes, H. Meugnier, F. Grimont, P. A. D. Grimont, C Nervi, and J. Fleurette. 1988. Staphylococcus lugdunensis sp. nov. and Staphylococcus schleiferi sp. nov., two species from human clinical specimens. Int. J. Syst. Bacteriol. 38:168-172.

12. Gherke, C. W., R. A. McCune, M. A. Gama-Sosa, M. Ehrlich, and K. C. Kuo 1984. Quantitative reversed-phase high-performance liquid chromatography of major and modified nucleosides in DNA. J. Chromatogr. 301:199-219.

13. Glauner, B., J. V. Holtje, and U. Schwarz. 1988. The composition of the murein of Escherichia coli. J. Biol. Chem. 263:10088-10095.

14. Grimont, P. A. D., M. Y. Popoff, F. Grimont, C. Coynaud, and M. Lemelin. 1980. Reproducibility and correlation study of three deoxyribonucleic acid hybridization procedures. Curr. Microbiol. 4:325-330.

15. Hájek, V. 1976. Staphylococcus intermedius, a new species isolated from animals. Int. J. Syst. Bacteriol. 26:401-408.

16. Hajek, V., and V. Horák. 1981. Typing of staphylococci with phages derived from Staphylococcus hyicus. Zentralbl. Bakteriol. Parasitenkd. Infektionskr. Hyg. Abt. 1 Suppl. 10:93-98.

17. Hájek, V., W. Ludwig, K. H. Schleifer, N. Springer, W. Zitzelsberger, R. M. Kroppenstedt, and M. Kocur. 1992. Staphylococcus muscae, a new species isolated from flies. Int. J. Syst. Bacteriol. 42:97-101.

18. Heath, L. S., G. L. Sloan, and H. E. Heath. 1986. A simple and generally applicable procedure for releasing DNA from bacterial cells. Appl. Environ. Microbiol. 51:1138-1140.

19. Holt, J. G., N. R. Krieg, P. H. A. Sneath, J. T. Staley, and S. T. Williams. 1994. Bergey's manual of determinative bacteriology, 9th ed. Williams \& Wilkins, Baltimore.
20. Howard, D. H. 1956. The preservation of bacteria by freezing in glycerol broth. J. Bacteriol. 71:625.

21. Janda, J. M. 1986. Elastolytic activity among staphylococci. J. Clin. Microbiol. 24:945-946.

22. Kaya, S., Y. Araki, and E. Ito. 1985. Characterization of a novel linkage unit between ribitol teichoic acid and peptidoglycan in Listeria monocytogenes cell walls. Eur. J. Biochem. 146:517-522.

23. Kloos, W. E., K. H. Schleifer, and R. F. Smith. 1976. Characterization of Staphylococcus sciuri sp. nov. and its subspecies. Int. J. Syst. Bacteriol. 26: 22-37.

24. Kloos, W. E., and J. F. Wolfshohl. 1991. Staphylococcus cohnii subspecies: Staphylococcus cohnii subsp. cohnii subsp. nov. and Staphylococcus cohnii subsp. urealyticum subsp. nov. Int. J. Syst. Bacteriol. 41:284-289.

25. Meyer, S. A., and K. H. Schleifer. 1978. Deoxyribonucleic acid reassociation of coagulase-positive staphylococci. Arch. Microbiol. 117:183-188.

26. Peyret, M., J. Freney, H. Meugnier, and J. Fleurette. 1989. Determination of $G+C$ content of DNA using HPLC for the identification of staphylococci and micrococci. Res. Microbiol. 140:467-475.

27. Schleifer, K. H., U. Geyer, R. Kilpper-Bälz, and L. A. Devriese. 1983. Elevation of Staphylococcus sciuri subsp. lentus (Kloos et al.) to species status: Staphylococcus lentus (Kloos et al.) comb. nov. Syst. Appl. Microbiol. 4:382387.

28. Schleifer, K. H., and O. Kandler. 1972. Peptidoglycan types of bacterial cell walls and their taxonomic implications. Bacteriol. Rev. 36:407-477.

29. Schleifer, K. H., R. Kilpper-Bälz, and L. A. Devriese. 1984. Staphylococcus arlettae sp. nov., $S$. equorum sp. nov. and $S$. kloosii sp. nov.: three new coagulase-negative, novobiocin-resistant species from animals. Syst. Appl. Microbiol. 5:501-509.

30. Schleifer, K. H., and W. E. Kloos. 1975. Isolation and characterization of staphylococci from human skin. I. Amended descriptions of Staphylococcus epidermidis and Staphylococcus saprophyticus and descriptions of three new species: Staphylococcus cohnii, Staphylococcus haemolyticus, and Staphylococcus xylosus. Int. J. Syst. Bacteriol. 25:50-61.

31. Schleifer, K. H., and R. M. Kroppenstedt. 1990. Chemical and molecular classification of staphylococci. J. Appl. Bacteriol. 69:9-24.

32. Subcommittee on Phage-Typing of Staphylococci. 1971. Report (1966-1970) of the Subcommittee on Phage-Typing of Staphylococci to the International Committee on Nomenclature of Bacteria. Int. J. Syst. Bacteriol. 21:167-170.

33. Subcommittee on Phage-Typing of Staphylococci. 1975. Report (1970-1974) of the Subcommittee on Phage-Typing of Staphylococci to the International Committee on Systematic Bacteriology. Int. J. Syst. Bacteriol. 25:241-242.

34. Tanasupawat, S., Y. Hashimoto, T. Ezaki, M. Kozaki, and K. Komagata. 1992. Staphylococcus piscifermentans sp. nov., from fermented fish in Thailand. Int. J. Syst. Bacteriol. 42:577-581.

35. Webster, J. A., T. L. Bannerman, R. J. Hubner, D. N. Ballard, E. M. Cole, J. L. Bruce, F. Fiedler, K. Schubert, and W. E. Kloos. 1994. Identification of the Staphylococcus sciuri species group with EcoRI fragments containing rRNA sequences and description of Staphylococcus vitulus sp. nov. Int. J. Syst. Bacteriol. 44:454-460.

36. Zakrzewska-Czerwińska, J., A. Gaszewska-Mastalarz, B. Lis, A. Gamian, and M. Mordarski. 1995. Staphylococcus pulvereri sp. nov., isolated from human and animal specimens. Int. J. Syst. Bacteriol. 45:169-172.

37. Zweig, G., and J. Sherm (ed.) 1984. Handbook of chromatography lipids, vol. I. CRC Press Inc., Boca Raton, Fla. 